Jurnal Ilmu Pertanian Agonitas Vol. 1 No.2 Edisi Oktober 2019

\title{
PERTUMBUHAN KEDELAI (Glycine max (L.) Merrill) YANG DIBERI MAGNESIUM DAN FOSFOR
}

\section{(Growth Of Soybean (Glycine Max (L.) Merrill) That Given Magnesium And Phosphorus)}

\author{
Syafran Jali $\left.{ }^{*} 1\right)$ \\ 1)Dosen Fakultas Pertanian Universitas Tamansiswa Palembang \\ *)Penulis untuk korespondensi: jalisyafran@gmail.com
}

\begin{abstract}
ABSTRAK
Penelitian ini bertujuan untuk melihat pengaruh pemupukan magnesium dan fosfor terhadap pertumbuhan kedelai. Penelitian ini menggunakan Rancangan Acak Kelompok (RAK) yang disusun secara faktorial dengan 24 kombinasi perlakuan dan setiap perlakuan diulang dua kali. Faktor-faktor yang diteliti adalah perlakuan Magnesium $\left(\mathrm{M}_{1}=52,50 \mathrm{~kg} \mathrm{MgCO}_{3}\right.$ ha-1, $\mathrm{M}_{2}=105,00$ $\mathrm{kg} \mathrm{MgCO}_{3} \mathrm{ha}^{-1}, \mathrm{M}_{3}=157,50 \mathrm{~kg} \mathrm{MgCO}_{3} \mathrm{ha}^{-1}, \mathrm{M} 4=210,00 \mathrm{~kg} \mathrm{MgCO}_{3} \mathrm{ha}^{-1}, \mathrm{M}_{5}=262,50 \mathrm{~kg} \mathrm{MgCO}_{3}$ $\left.\mathrm{ha}^{-1}, \mathrm{M}_{6}=315,00 \mathrm{~kg} \mathrm{MgCO}_{3} \mathrm{ha}^{-1}\right)$ dan perlakuan Fosfor ( $\mathrm{P}_{0}=$ tanpa pemupukan, $\mathrm{P}_{1}=104,56 \mathrm{~kg}$ SP-36 ha-1 $\left.\mathrm{P}_{2}=209,12 \mathrm{~kg} \mathrm{SP}-36 \mathrm{ha}^{-1}, \mathrm{P}_{3}=313,67 \mathrm{~kg} \mathrm{SP}^{-36} \mathrm{ha}^{-1}\right)$. Hasil penelitian menunjukkan bahwa perlakuan $\mathrm{Mg}$ dan $\mathrm{P}$ secara bersamaan berpengaruh terhadap tinggi tanaman periode tumbuh delapan minggu, LTT periode tumbuh empat dan enam minggu, dan ILD periode tumbuh delapan minggu setelah tanam, perlakuan $\mathrm{Mg}$ dan $\mathrm{P}$ secara terpisah berpengaruh terhadap tinggi tanaman, LTT, LAB, ILD, dan NPA, dan kombinasi perlakuan $\mathrm{M}_{4} \mathrm{P}_{1}$ dengan takaran pupuk $\mathrm{Mg}$ sebesar $210,00 \mathrm{~kg} \mathrm{MgCO}_{3} \mathrm{ha}^{-1}$ dan pupuk $\mathrm{P}$ sebesar 104,56 kg SP-36 ha-1 memberikan pengaruh yang paling baik terhadap tinggi tanaman, LTT, dan ILD.
\end{abstract}

Kata kunci: kedelai, magnesium, posfor.

\begin{abstract}
This study aims to look at the effect of fertilizing magnesium and phosphorus on soybean growth. This study used a randomized block design (RBD) factorially arranged with 24 treatment combinations and each treatment was repeated twice. The factors studied were the treatment of Magnesium (M1 = $52.50 \mathrm{~kg} \mathrm{MgCO} 3$ ha- $1, \mathrm{M} 2=105.00 \mathrm{~kg} \mathrm{MgCO} 3$ ha- $1, \mathrm{M} 3=157.50 \mathrm{~kg} \mathrm{MgCO} 3$ ha- $1, \mathrm{M} 4=210.00 \mathrm{~kg} \mathrm{MgCO} 3$ ha $-1, \mathrm{M} 5=262.50 \mathrm{~kg} \mathrm{MgCO} 3$ ha-1, M6 = $315.00 \mathrm{~kg} \mathrm{MgCO}$ ha-1) and Phosphorus treatment $(\mathrm{PO}=$ without fertilizing, $\mathrm{P} 1=104.56 \mathrm{~kg}$ SP-36 ha-1, P2 = 209, $12 \mathrm{~kg}$ SP-36 ha-1, P3 = 313.67 kg SP-36 ha-1). The results showed that the Mg and P treatments simultaneously affected the plant height of the eight-week growing period, the LTT growing period of four and six weeks, and the ILD growing period eight weeks after planting, the Mg and $\mathrm{P}$ treatment separately affected the plant height, LTT, LAB , ILD, and NPA, and the combination of M4P1 treatment with a dose of $\mathrm{Mg}$ fertilizer of $210.00 \mathrm{~kg} \mathrm{MgCO} 3 \mathrm{ha}-1$ and P fertilizer of $104.56 \mathrm{~kg} \mathrm{SP}-36$ ha-1 gave the best effect on plant height, LTT, and ILD .
\end{abstract}

Keyword: soybean, magnesium, phosphorus 


\section{PENDAHULUAN}

\section{A. Latar Belakang}

Kedelai (Glycine max (L.) Merrill) merupakan tanaman pangan ketiga terpenting di Indonesia setelah padi dan jagung. Kedelai mempunyai prospek yang baik dikembangkan di Indonesia, karena merupakan sumber protein yang relatif murah (Djafar, 1984). Selanjutnya Sumarno (1984) menambahkan bahwa kedelai dibutuhkan oleh masyarakat terutama besar peranannya dalam pencukupan protein, setidak-tidaknya sementara produksi protein hewani belum mencukupi.

Biji kedelai kaya akan protein yaitu 35 persen sampai 45 persen. Juga mengandung lemak, mineral dan beberapa vitamine sehingga sangat cocok sebagai sumber energi dan mineral (Sumarno dan Hartono, 1983).

Usaha untuk meningkatkan produksi kedelai dapat dilakukan dengan jalan intensifikasi, ekstensifikasi, deversifikasi dan rehabilitasi budidaya tanaman. Usaha pemanfaatan sumber daya lahan pertanian yang berpontensi untuk perluasan budidaya tanaman, terutama pada lahan kering merupakan jalan terbaik dalam pengembangan tanaman kedelai di Indonesia. Akan tetapi usaha tersebut sering tidak berhasil, karena lahan kering yang tersebar luas di seluruh kepulauan Indonesia pada umumnya didominasi oleh jenis tanah podsolik (Ardjasa, Ismail dan Sumarno, 1984).

Menurut Leiwakabessy (1977), lahan kering dengan jenis tanah Podsolik Merah Kuning mempunyai $\mathrm{pH}$ tanah yang rendah dan miskin unsur hara. Hal ini merupakan faktor pembatas bagi tercapainya produksi yang tinggi pada lahan tersebut.

Sebagaimana tanaman lain kedelai juga banyak membutuhkan unsur hara yang esensial untuk pertumbuhannya. Unsur hara tersebut antara lain unsur hara $\mathrm{Mg}$ dan $\mathrm{P}$.

Derajat kemasaman tanah $(\mathrm{pH})$ dapat ditingkatkan dengan menambahkan $\mathrm{Mg}$, karena peranan $\mathrm{Mg}$ selain sebagai penyusun khlorofil dan proses metabolisme di dalam tanaman juga dapat menggantikan kedudukan ion hidrogen dari kompleks adsorpsi. Dengan demikian $\mathrm{Mg}$ dapat mengurangi efek kemasaman tanah, akibatnya $\mathrm{pH}$ tanah akan meningkat (Hakim, Nyakpa, Lubis, Nugroho, Saul, Diha, Go dan Bailey, 1986). Sedangkan fosfor (P) banyak berperan dalam pembelahan sel, pembentukan bunga, buah dan biji, menyeragamkan kematangan buah, merangsang perkembangan akar (Soepardi, 1983). Selanjutnya Pasaribu dan Suprapto (1985) mengemukakan bahwa P ber pengaruh positif terhadap tinggi tanaman, jumlah cabang, jumlah polong serta menaikkan jumlah bintil akar.

Oleh karena itu perlu diadakan penelitian untuk melihat pengaruh $\mathrm{Mg}$ dan $\mathrm{P}$ terhadap pertumbuhan kedelai.

\section{B. Tujuan Penelitian}

Penelitian ini bertujuan untuk melihat pengaruh pemupukan magnesium dan fosfor terhadap pertumbuhan kedelai.

\section{Hipotesis}

Diduga dengan meningkatkan takaran magnesium dan fosfor yang diberikan akan meningkatkan pertumbuhan tanaman sampai batas maksimum.

\section{BAHAN DAN METODE PENELITIAN}

\section{A. Tempat dan Waktu}

Penelitian dilaksanakan di Kebun Percobaan Fakultas Pertanian Universitas Tamansiswa Palembang pada ketinggian lima meter dari permukaan laut dengan jenis tanah Podsolik Merah Kuning. Pelaksanaannya dimulai pada bulan Januari 2018 sampai dengan bulan Maret 2018.

\section{B. Bahan dan Alat}

Bahan-bahan yang digunakan dalam penelitian ini adalah : benih kedelai varietas Orba, pupuk $\mathrm{MgCO}_{3}$ dan SP-36, legin, fungisida, insektisida serta pupuk kandang sebanyak 10 ton ha-1. Alat-alat yang digunakan dalam penelitian ini adalah : mistar pengukur, kantong plastik, cangkul,gunting, timbangan, kertas, ajir.

\section{Metode Penelitian}


Metode yang digunakan adalah Rancangan Acak Kelompok (RAK) yang disusun secara faktorial dengan 24 kombinasi perlakuan dan setiap perlakuan diulang dua kali. Faktorfaktor yang diteliti adalah sebagai berikut :

1. Perlakuan Magnesium.

$$
\begin{aligned}
& M_{1}=52,50 \mathrm{~kg} \mathrm{MgCO}_{3} \mathrm{ha}^{-1} \\
& M_{2}=105,00 \mathrm{~kg} \mathrm{MgCO}_{3} \text { ha-1 }^{-1} \\
& M_{3}=157,50 \mathrm{~kg} \mathrm{MgCO}_{3} \mathrm{ha}^{-1} \\
& M_{4}=210,00 \mathrm{~kg} \mathrm{MgCO}_{3} \mathrm{ha}^{-1} \\
& M_{5}=262,50 \mathrm{~kg} \mathrm{MgCO}_{3} \mathrm{ha}^{-1}
\end{aligned}
$$

2. Perlakuan Fosfor.

$$
\begin{aligned}
& P_{0}=\text { tanpa pemupukan } \\
& P_{1}=104,56 \mathrm{~kg} \mathrm{SP}-36 \mathrm{ha}^{-1} \\
& P_{2}=209,12 \mathrm{~kg} \mathrm{SP}-36 \mathrm{ha}^{-1} \\
& P_{3}=313,67 \mathrm{~kg} \mathrm{SP}-36 \mathrm{ha}^{-1}
\end{aligned}
$$

Analisis data hasil pengukuran parameter pertumbuhan didekati dengan teknik analisis tumbuh. Adapun kombinasi perlakuan tersebut disajikan pada Tabel 1.

Tabel 1. Kombinasi perlakuan Magnesium dan Fosfor.

\begin{tabular}{ccccc}
\hline Magnesium & \multicolumn{5}{c}{ Fosfor } \\
\cline { 2 - 5 } & $\mathrm{P}_{0}$ & $\mathrm{P}_{1}$ & $\mathrm{P}_{2}$ & $\mathrm{P}_{3}$ \\
\hline$M_{1}$ & $M_{1} \mathrm{P}_{0}$ & $\mathrm{M}_{1} \mathrm{P}_{1}$ & $\mathrm{M}_{1} \mathrm{P}_{2}$ & $\mathrm{M}_{1} \mathrm{P}_{3}$ \\
$M_{2}$ & $M_{2} \mathrm{P}_{0}$ & $\mathrm{M}_{2} \mathrm{P}_{1}$ & $\mathrm{M}_{2} \mathrm{P}_{2}$ & $\mathrm{M}_{2} \mathrm{P}_{3}$ \\
$M_{3}$ & $M_{3} \mathrm{P}_{0}$ & $\mathrm{M}_{3} \mathrm{P}_{1}$ & $\mathrm{M}_{3} \mathrm{P}_{2}$ & $\mathrm{M}_{3} \mathrm{P}_{3}$ \\
$M_{4}$ & $\mathrm{M}_{4} \mathrm{P}_{0}$ & $\mathrm{M}_{4} \mathrm{P}_{1}$ & $\mathrm{M}_{4} \mathrm{P}_{2}$ & $\mathrm{M}_{4} \mathrm{P}_{3}$ \\
$M_{5}$ & $M_{5} \mathrm{P}_{0}$ & $\mathrm{M}_{5} \mathrm{P}_{1}$ & $\mathrm{M}_{5} \mathrm{P}_{2}$ & $\mathrm{M}_{5} \mathrm{P}_{3}$ \\
$M_{6}$ & $\mathrm{M}_{6} \mathrm{P}_{0}$ & $\mathrm{M}_{6} \mathrm{P}_{1}$ & $\mathrm{M}_{6} \mathrm{P}_{2}$ & $\mathrm{M}_{6} \mathrm{P}_{3}$ \\
\hline
\end{tabular}

\section{Pelaksanaan Penelitian}

Tahapan kerja yang dilaksanakan dalam penelitian ini disajikan dalam uraian berikut: persiapan lahan, pemupukan, penanaman dan pemeliharaan.

Tanah diolah dengan cangkul kemudian dibuat petakan dengan ukuran 2,25 m x 4,00 m. Pupuk kandang ditebarkan setiap petakan keudian tanahnya dihaluskan dengan cangkul.

Pupuk $\mathrm{MgCO}_{3}$ dan SP-36 sebagai perlakuan diberikan sesuai dengan takaran secara larikan. Pemberian pupuk dilakukan sebelum benih ditugal. Jarak larikan pupuk dengan lobang benih $10 \mathrm{~cm}$.

Kedelai ditanam secara tugal sedalam tiga sampai lima $\mathrm{cm}$ dengan jarak tanam $25 \mathrm{~cm}$ $x 25 \mathrm{~cm}$. Setiap lobang tugal ditabur tiga sampai lima benih kedelai yang telah diinokulasi dengan legin.

Penyulaman dan penjarangan dilakukan setelah bibit berumur tujuh hari setelah tanam dan dipelihara dua tanaman rumpun-1. Penyiraman di lakukan pada pagi dan sore hari sesuai dengan keadaan tanah. Usaha pencegahan terhadap serangan hama dan penyakit dilakukan penyemprotan insektisida dan fungisida setiap satu minggu sekali. Pada umur 10 hari dilakukan penyiangan gulma kemudian setiap petak perlaku an diberi mulsa untuk mengurangi tumbuhnya gulma dan evaporasi.

\section{E. Pengumpulan Data}

Data yang dikumpulkan meliputi tinggi tanaman, luas daun dan bobot bahan kering yang diukur setiap dua minggu sekali.

Tinggi tanaman diukur mulai dari leher akar sampai titik tumbuh. Pengamatan dilakukan setiap dua minggu sekali selama empat kali pengamatan dengan dicabut semua bagian tanaman. Tanaman contoh petak $^{-1}$ perlakuan diamati sejumlah 12 rumpun seluas $0,75 \mathrm{~m}^{2}$.

Luas daun diukur dengan menggunakan metode blue print (Blue print method). Rumus luas daun disajikan sebagai berikut :

$$
A=\frac{Y^{\prime}}{Y} \times(p \times I)
$$




$$
\text { Dimana: } \begin{aligned}
A & =\text { luas daun } \\
Y^{\prime} & =\text { bobot kertas pola daun } \\
Y & =\text { bobot kertas semula } \\
& =\text { panjang kertas } \\
& =\text { lebar kertas }
\end{aligned}
$$

Bobot bahan kering tanaman didapatkan dengan menimbang tanam an yang telah dikeringovenkan pada suhu $70^{\circ} \mathrm{C}$ selama 48 jam. Setelah data luas daun dan bobot bahan kering tanaman didapatkan, maka data tersebut diolah dengan analisis tumbuh yang meliputi : LTT, LAB, ILD dan nisbah antara pupus dengan akar.

\section{HASIL DAN PEMBAHASAN}

\section{A. Hasil}

Hasil analisis statistik didapatkan bahwa interaksi pemupukan $\mathrm{Mg}$ dan $\mathrm{P}$ berpengaruh terhadap tinggi tanaman (TT) umur delapan minggu, laju tumbuh tanaman (LTT) umur empat dan enam minggu dan indeks luas daun (ILD) umur delapan minggu setelah tanam. Hasil analisis statistik di atas kemudian dilanjutkan dengan uji BNJ untuk masing-masing parameter

Tinggi tanaman (TT) merupakan salah satu parameter pertumbuhan yang dipengaruhi secara terpisah oleh takaran pupuk $\mathrm{Mg}$ dan $\mathrm{P}$ pada periode tumbuh dua, empat, dan enam minggu setelah tanam. Pada periode tumbuh delapan minggu setelah tanam TT dipengaruhi secara bersamaan oleh takaran $\mathrm{Mg}$ dan $\mathrm{P}$. Hasil uji BNJ terhadap TT periode tumbuh delapan minggu setelah tanam disajikan pada Tabel 2.

Dari Tabel 2 terlihat bahwa pada kondisi $\mathrm{P}_{1}$ dengan meningkatkan takaran pupuk $\mathrm{Mg}$ sampai $\mathrm{M}_{4}$ diikuti oleh meningkatnya TT pada periode tumbuh delapan minggu setelah tanam. Akan tetapi TT tidak bertambah walaupun penggunaan pupuk $\mathrm{Mg}$ lebih tinggi dari $\mathrm{M}_{4}$. Begitu juga pada $\mathrm{P}_{2}$.

Tabel 2. Uji BNJ pengaruh interaksi perlakuan Mg dan $\mathrm{P}$ terhadap tinggi tanaman periode tumbuh delapan minggu setelah tanam.

\begin{tabular}{cllll}
\hline Magnesium & \multicolumn{4}{c}{ Fospor } \\
\cline { 2 - 5 } & P0 & P1 & P2 & P3 \\
\hline M1 & $32,75 \mathrm{i}$ & $40,90 \mathrm{bcd}$ & $39,25 \mathrm{cdef}$ & 36,80 defghi \\
M2 & $33,60 \mathrm{i}$ & $41,85 \mathrm{bc}$ & $40,25 \mathrm{~cd}$ & 36,90 defghi \\
M3 & $34,00 \mathrm{hi}$ & $45,10 \mathrm{ab}$ & $42,45 \mathrm{abc}$ & $38,30 \mathrm{cdefgh}$ \\
M4 & 35,70 efghi & $46,10 \mathrm{a}$ & $44,90 \mathrm{ab}$ & $40,25 \mathrm{~cd}$ \\
M5 & $34,50 \mathrm{ghi}$ & $39,75 \mathrm{cde}$ & $39,20 \mathrm{cdef}$ & $38,70 \mathrm{cdefg}$ \\
M6 & $34,50 \mathrm{ghi}$ & 35,60 efghi & 35,50 efghi & $35,15 \mathrm{fghi}$ \\
\hline
\end{tabular}

BNJ $0,01=4,40$

Keterangan : Angka-angka yang diikuti huruf yang sama berbeda tidak nyata taraf uji 0,01 .

Untuk laju tumbuh tanaman (LTT) dipengaruhi oleh takaran pupuk $\mathrm{Mg}$ dan $\mathrm{P}$ secara terpisah pada periode tumbuh dua minggu setelah tanam. Sedangkan untuk periode tumbuh empat dan enam minggu setelah tanam LTT dipengaruhi secara bersamaan oleh takaran $\mathrm{Mg}$ dan P. Akan tetapi pada periode tumbuh delapan minggu setelah tanam takaran pupuk $\mathrm{Mg}$ dan $\mathrm{P}$ tidak berpengaruh terhadap LTT. LTT pada periode tumbuh empat minggu setelah tanam meningkat dengan penggunaan pupuk $\mathrm{Mg}$ dan $\mathrm{P}$. Dengan meningkatkan takaran pupuk $\mathrm{Mg}$ sampai $\mathrm{M}_{4}$ pada penggunaan pupuk $P$ sampai $P_{1}$ dan $P_{2}$ LTT meningkat. LTT mencapai maksimum pada perlakuan $\mathrm{M}_{4} \mathrm{P}_{1}$ yakni 39,22 g.m ${ }^{-2}$. minggu-1 (Tabel 3). Akan tetapi pada $\mathrm{P}_{3}$ penggunaan pupuk $\mathrm{Mg}$ yang lebih tinggi dari $157,50 \mathrm{~kg}$ $\mathrm{MgCO}_{3}$ ha-1 LTT akan menurun.

Pada kondisi $M_{1}, M_{2}, M_{5}$, dan $M_{6}$ meningkatnya penggunaan $P$ sampai $P_{1}$ akan meningkatkan LTT. Sedangkan pada $M_{3}$ dan $M_{6}$ 
meningkatnya pupuk $P$ tidak akan meningkatkan LTT. Hasil uji BNJ pada periode tumbuh empat

dan enam minggu setelah tanam masingmasing disajikan pada Tabel 3 dan Tabel 4.

Tabel 3. Uji BNJ pengaruh interaksi perlakuan Mg dan P terhadap LTT periode tumbuh empat minggu setelah tanam

\begin{tabular}{cllll}
\hline Magnesium & \multicolumn{4}{c}{ Fospor } \\
\cline { 2 - 5 } & P0 & P1 & P2 & P3 \\
\hline M1 & $17,72 \mathrm{n}$ & $25,43 \mathrm{fghij}$ & $25,08 \mathrm{ghij}$ & $24,33 \mathrm{hijk}$ \\
M2 & $20,93 \mathrm{klmn}$ & $28,70 \mathrm{defg}$ & $26,01 \mathrm{fghi}$ & $25,08 \mathrm{ghij}$ \\
M3 & $21,78 \mathrm{jklm}$ & $30,79 \mathrm{cde}$ & $29,86 \mathrm{cde}$ & $32,05 \mathrm{~cd}$ \\
M4 & $22,56 \mathrm{ijkl}$ & $39,22 \mathrm{a}$ & $36,54 \mathrm{ab}$ & $32,76 \mathrm{bc}$ \\
M5 & $19,58 \mathrm{lmn}$ & $28,99 \mathrm{cdef}$ & $28,90 \mathrm{def}$ & $27,67 \mathrm{efgh}$ \\
M6 & $18,60 \mathrm{mn}$ & $24,64 \mathrm{hijk}$ & $22,20 \mathrm{ijklm}$ & $22,11 \mathrm{jklm}$ \\
\hline
\end{tabular}

BNJ 0,01 = 3,82

Keterangan : Angka-angka yang diikuti huruf yang sama berbeda tidak nyata taraf uji 0,01.

Tabel 4. Uji BNJ pengaruh interaksi perlakuan Mg dan P terhadap LTT periode tumbuh enam minggu setelah tanam

\begin{tabular}{cllll}
\hline Magnesium & \multicolumn{4}{c}{ Fospor } \\
\cline { 2 - 5 } & P0 & P1 & P2 & P3 \\
\hline M1 & $28,72 \mathrm{I}$ & $57,34 \mathrm{def}$ & $45,46 \mathrm{hi}$ & $39,49 \mathrm{jjk}$ \\
M2 & $35,41 \mathrm{jkl}$ & $60,88 \mathrm{de}$ & $53,24 \mathrm{fgh}$ & $51,92 \mathrm{fgh}$ \\
M3 & $35,80 \mathrm{jkl}$ & $63,90 \mathrm{bcd}$ & $62,08 \mathrm{~cd}$ & $58,62 \mathrm{def}$ \\
M4 & $39,68 \mathrm{ij}$ & $75,67 \mathrm{a}$ & $70,37 \mathrm{ab}$ & $68,95 \mathrm{abc}$ \\
M5 & $31,41 \mathrm{l}$ & $75,10 \mathrm{a}$ & $52,48 \mathrm{fgh}$ & $46,14 \mathrm{ghi}$ \\
M6 & $30,45 \mathrm{I}$ & $53,88 \mathrm{efg}$ & $42,16 \mathrm{ij}$ & $32,43 \mathrm{kl}$ \\
\hline
\end{tabular}

BNJ 0,01 = 7,22

Keterangan : Angka-angka yang diikuti huruf yang sama berbeda tidak nyata taraf uji 0,01.

Hasil analisis statistik menunjukkan pada periode tumbuh delapan minggu setelah bahwa pada periode tumbuh dua, empat, dan tanam ILD dipengaruhi secara bersamaan oleh enam minggu setelah tanam pemupukan $\mathrm{Mg}$ besarnya takaran $\mathrm{Mg}$ dan $\mathrm{P}$. Hasil uji BNJ dan disertai pupuk $\mathrm{P}$ tidak berpengaruh terhadap ILD periode tumbuh delapan minggu terhadap indeks luas daun (ILD). Sedangkan setelah tanam disajikan pada Tabel 5.

Tabel 5. Uji BNJ pengaruh interaksi perlakuan Mg dan P terhadap ILD periode tumbuh delapan minggu setelah tanam

\begin{tabular}{cllll}
\hline Magnesium & \multicolumn{3}{c}{ Fospor } \\
\cline { 2 - 5 } & P0 & P1 & P2 & P3 \\
\hline M1 & 1,36 I & 2,08 ef & 2,04 ef & $1,63 \mathrm{ijk}$ \\
M2 & $1,66 \mathrm{hijk}$ & $2,54 \mathrm{~cd}$ & $2,43 \mathrm{~cd}$ & $1,95 \mathrm{efghi}$ \\
M3 & $1,71 \mathrm{ghijk}$ & $2,95 \mathrm{~b}$ & $2,56 \mathrm{~cd}$ & $2,02 \mathrm{efg}$ \\
M4 & $1,98 \mathrm{efgh}$ & $3,37 \mathrm{a}$ & $2,61 \mathrm{c}$ & $2,26 \mathrm{de}$ \\
M5 & $1,80 \mathrm{fghij}$ & $3,00 \mathrm{~b}$ & $2,02 \mathrm{efg}$ & $1,65 \mathrm{ijkl}$ \\
M6 & $1,41 \mathrm{kl}$ & $2,00 \mathrm{efg}$ & $1,51 \mathrm{jkl}$ & $1,41 \mathrm{kl}$ \\
\hline
\end{tabular}

BNJ 0,01 =0,32

Keterangan : Angka-angka yang diikuti huruf yang sama berbeda tidak nyata taraf uji 0,01 
Pada kondisi $\mathrm{P}_{1}$ dengan meningkatkan takaran pupuk $\mathrm{Mg}$ sampai $\mathrm{M}_{4}$ akan meningkatkan ILD. Akan tetapi pada takaran $\mathrm{Mg}$ yang lebih tinggi ILD tidak meningkat. Sedangkan pada $\mathrm{P}_{2}$ meningkatnya pupuk $\mathrm{Mg}$ sampai $\mathrm{M}_{2}$ diikuti oleh meningkatnya ILD. Akan tetapi ILD menurun setelah takaran $\mathrm{M}_{2}$ tercapai. Pada $\mathrm{P}_{3}$ dengan meningkatkan $\mathrm{Mg}$ sampai $\mathrm{M}_{3}$ akan meningkatkan ILD.

\section{B. Pembahasan}

Tanaman kedelai yang tertinggi pada minggu terakhir pengamatan adalah dicapai oleh perlakuan $\mathrm{M}_{4} \mathrm{P}_{1}$ yakni $46,50 \mathrm{~cm}$. Sedangkan perlakuan terendah dicapai oleh perlakuan $M_{1} P_{0}$ yakni $32,75 \mathrm{~cm}$. Meningkatnya tinggi tanaman akibat pemupukan $\mathrm{Mg}$ dan $\mathrm{P}$ diduga ada hubungannya dengan pembentukan nodula pada akar dan aktivitas bakteri Rhizobium yang dapat memfiksasi $\mathrm{N}_{2}$ dari udara (Jones, Lutz dan Smith, 1977 dan Cassman, Whitney dan Fox, 1981). Mengel dan Kirby (1979) mengatakan bahwa untuk meningkatkan fiksasi $\mathrm{N}_{2}$ dari udara, bakteri Rhizobium memerlukan energi (ATP) yang diperoleh dari hasil fotosintesis tanaman inang. Dengan demikian apabila terjadi hambatan pada aktivitas fotosintesis akibat kekurangan $\mathrm{P}$, maka fotosintat yang dihasilkan akan berkurang. Hambatan tersebut akan mengurangi suplai fotosintat ke akar, akibatnya fotosintat yang diterima oleh akar dan bakteri Rhizobium berkurang sehingga aktivitas bakteri tersebut berkurang dan fiksasi $\mathrm{N}_{2}$ dari udara menurun sehingga tidak dapat menyediakan $\mathrm{N}$ dalam jumlah yang cukup bagi pertumbuhan tanaman kedelai.

Menurut Bidwell (1979), P berperan di dalam tanaman sebagai pembangun nucleoprotein di dalam inti sel. Pembentukan sel-sel baru hanya dapat berlangsung dengan pembelahan inti sel. Dengan demikian apabila kekurangan $P$ pada media pertumbuhan tanaman akan menghambat proses pembelahan sel dan akibatnya pertumbuhan tanaman akan terhambat.

Laju tumbuh tanaman (LTT) dipengaruhi secara bersamaan oleh takaran pupuk $\mathrm{Mg}$ dan
$P$ yang digunakan pada periode tumbuh empat dan enam minggu setelah tanam. LTT meningkat akibat penggunaan pupuk Mg sampai $\mathrm{M}_{4}$. Akan tetapi pada penggunaan pupuk $\mathrm{Mg}$ yang lebih tinggi dari $\mathrm{M}_{4} \mathrm{LTT}$ menurun.

LTT mencapai maksimum pada periode tumbuh enam minggu setelah tanam. Sedangkan pada periode tumbuh delapan minggu setelah tanam LTT cenderung menurun. Hal ini sejalan dengan percobaan yang dilakukan oleh Djafar (1984), laju tumbuh tanaman meningkat dengan cepat pada awal fase pertumbuhan vegetatif hingga tanaman berumur 50 hari setelah tanam, kemudian menurun setelah umur tersebut tercapai. Menurunnya nilai LTT disebabkan oleh menurunnya nilai LAB dan ILD (Radford, 1967). Scott dan Batchelor

menambahkan bahwa pada fase reproduktif bobot kering daun dan batang menurun dengan cepat dan tidak seimbang dengan laju pertumbuhan polong. Sebelumnya Buttery (1969) mengemukakan bahwa menurunnya LTT antara lain disebabkan berkurangnya cahaya yang diterima oleh tanaman, meningkatnya pembentukan polong dan biji serta adanya daun-daun yang menguning dan menjadi tua. Selanjutnya Suseno (1974) menyatakan bahwa semakin tua umur tanaman semakin besar pula respirasi yang terjadi. Sehingga hasil fotosintesis tidak seimbang dengan hasil respirasi, akibatnya nilai LTT pada fase reproduksi menurun.

Indeks luas daun (ILD) pada periode tumbuh delapan minggu setelah tanam dipengaruhi oleh penggunaan pupuk $\mathrm{Mg}$ dan $\mathrm{P}$. Nilai ILD tertinggi dicapai oleh perlakuan $\mathrm{M}_{4} \mathrm{P}_{1}$ yakni $3,37 \mathrm{~m}^{2} \cdot \mathrm{m}^{-2}$. Sedangkan nilai ILD terendah dicapai oleh perlakuan $\mathrm{M}_{1} \mathrm{P}_{0}$ yakni 1,36 $\mathrm{m}^{2} \cdot \mathrm{m}^{-2}$ (Tabel 6).

Menurut Radford (1967) semakin besar nilai luas daun semakin luas pula areal tempat tumbuh suatu tanaman. Buttery (1970) mendapatkan ILD optimum bagi kedelai adalah 3,20 sampai $3,53 \mathrm{~m}^{2} \cdot \mathrm{m}^{-2}$. Sedangkan pada percobaan ini perlakuan $\mathrm{M}_{4} \mathrm{P}_{1}$ sudah mencapai nilai ILD tertinggi yakni $3,37 \mathrm{~m}^{2} \cdot \mathrm{m}^{-2}$. 
Nilai ILD meningkat dan mencapai maksimum sampai saat mulai berbunga yaitu tanaman berumur delapan minggu setelah tanam. Hal ini disebabkan pada masa vegetatif fotosintesis yang dihasilkan banyak diguhakan untuk pembentukan daun dan khlorofil sebagai prasarana untuk aktivitas fotosintesis (Scott dan Bachelor, 1979).

\section{KESIMPULAN DAN SARAN}

\section{A. Kesimpulan}

Dari hasil penelitian dan pembahasan dapat disimpulkan hal-hal sebagai berikut :

1. Perlakuan $\mathrm{Mg}$ dan $\mathrm{P}$ secara bersamaan berpengaruh terhadap tinggi tanaman periode tumbuh delapan minggu, LTT periode tumbuh empat dan enam minggu, dan ILD periode tumbuh delapan minggu setelah tanam,

2. Perlakuan $\mathrm{Mg}$ dan $\mathrm{P}$ secara terpisah berpengaruh terhadap tinggi tanaman, LTT, LAB, ILD, dan NPA, dan

3. Kombinasi perlakuan $\mathrm{M}_{4} \mathrm{P}_{1}$ dengan takaran pupuk $\mathrm{Mg}$ sebesar $210,00 \mathrm{~kg} \mathrm{MgCO}_{3} \mathrm{ha}^{-1}$ dan pupuk P sebesar 104,56 kg SP-36 ha-1 memberikan pengaruh yang paling baik terhadap tinggi tanaman, LTT, dan ILD.

\section{B. Saran}

Dari hasil penelitian dan maka dapat disaranlkan hal-hal sebagai berikut :

1. Untuk mendapatkan hasil penelitian yang lebih mantap diharapkan adanya periode pengamatan yang lebih pendek yaitu setiap minggu,

2. Dalam usaha peningkatan produksi kedelai perlu kiranya ditambah paket pupuk $\mathrm{Mg}$ selain pupuk NPK.

\section{DAFTAR PUSTAKA}

Ardjasa, W. S., I. G. Ismail dan Sumarno. 1984. Usaha Tani Tanaman Kedelai Pada Lahan Kering Podsolik di Daerah Sumatera Selatan. Makalah Pada Pertemuan Teknis PPS se-Sumatera Selatan di Belitang, 7-8 Nopember 1984. 15 hal.
Bidwell, R. G. S. 1979. Plant Physiology. Macmillan Publ. Co. Inc., New York. $709 p$.

Buttery, B. R. 1969. An Analysis of Growth of Soybeans as Affected by Plant Population and Firtilizer. Can. J. Plant Sci. 49: 675-674.

1970. Effects of Variation in Leaf Area Index on Growth of Maize dan Soybean. Crop Sci. 10: 9-13.

Cassman, K. G., A. S. Whtney and R. L. Fox. 1981. Phophorus Requirement of Soybean and Cowpea as Affected by mode of N Nutrition. Agron. J. 73: 1722.

Djafar, Z. R. 1984a. Kedelai (Glycine max (L.) Merrill). Jurusan Budi Daya Pertanian. Fakultas Pertanian Unsri Palembang. 22 hal.

1984b. Effisiensi Serapan Hara Fosfor oleh Tanaman Kedelai (Glycine max (L.) Merrill). Disertasi Pasca Sarjana Universitas Padjadjaran Bandung, Bandung.

Hakim, N., M. Y. Nyakpa., A. M. Lubis., S. G. Nugroho., M. R. Saul., M. A. Diha., Ban Hong, Go dan H. H. Bailey. 1986. Dasar-dasar Ilmu Tanah. Universitas Lampung, Lampung. 488 hal.

Jones, G. D., J. A. Lutz, Jr and T. J. Smith. 1977. Effets of Phophorus and Potassium on Soybean Nodules and Seed Yield. Agron. J. 69: 10031006.

Leiwakabessy, F. M. 1977. Bahan Kuliah Kesuburan Tanah. Jurusan Tanah Fakultas Pertanian, IPB. Bogor. 3: 11 $-16$. 
Mengel, K. and E. A. Kirkby. 1979. Principles of Plant Nutrition. Printed by Der Bund, AG. Bern. 593 p.

Pasaribu, D. dan S. Suprapto. 1985. Pemupukan NPK Pada Kedelai. Dalam Kedelai. Balai Penelitian Tanaman Pangan Bogor. Hal 159 169.

Radford, P. J. 1967. Growth Analysis Formulae-Their Use and Abuse. Crop Sci. $7: 171-175$.

Scott, H. D. and J. T. Batchelor. 1979. Dry Weight and Leaf Area Production Rate of Irrigated Determinate Soybeans. Agron. J. 71: $776-782$.

Soepardi, G. 1983. Sifat dan Ciri Tanah. Departemen IImu-ilmu Tanah. Fakultas Pertanian IPB, Bogor. 591 hal.

Sumarno. 1984. Kedelai dan Cara Budidayanya. CV Yasaguna Jakarta. 110 hal.

Sumarno dan Hartono. 1983. Kedelai dan Cara Bercocok Tanamnya. Pusat Penel;itian dan Pengembangan Tanaman Pangan. Buletin Teknik No. 6. 53 hal.

Suseno, H. 1974. Fisiologi Tumbuhan, Metabolisme Dasar. Departemen Botani Fakultas Pertanian IPB, Bogor. 277 hal. 